\title{
Dynamic control of the T-cell specification gene regulatory network
}

\author{
Ellen V. Rothenberg \\ Division of Biology \& Biological Engineering, California Institute of Technology, Pasadena, CA \\ 91125, USA.
}

\section{Abstract}

Specification of multipotent blood precursor cells in postnatal mice to become committed T-cell precursors involves a gene regulatory network of several interacting but functionally distinct modules. Many links of this network have been defined by perturbation tests and by functional genomics. However, using the network model to predict real-life kinetics of the commitment process is still difficult, partly due to the tenacity of repressive chromatin states, and to the ability of transcription factors to affect each other's binding site choices through competitive recruitment to alternative sites ("coregulator theft"). To predict kinetics, future models will need to incorporate mechanistic information about chromatin state change dynamics and more sophisticated understanding of the proteomics and cooperative DNA site choices of transcription factor complexes.

\section{Keywords}

Gene regulatory network; Transcription factors; Notch signaling; Functional genomics; Epigenetic constraints; System dynamics; Topological model; T cell development

\section{Introduction}

T cell development is a particularly accessible system for studying the sequence of regulatory changes through which stem and progenitor cells resolve their multipotency to select a particular differentiation pathway. Multipotent blood (hematopoietic) precursor cells are driven to a T-cell fate by sustained Notch-pathway signaling, after they enter the thymus [1](see reviews [2-5]). In the process, the cells downregulate a large battery of stem- and progenitor-associated regulatory factors, upregulate T-lineage associated regulatory factors, undergo commitment to the T-cell fate, and then upregulate recombinase-activating gene (RAG) 1 and 2 expression to execute recombination at the T-cell receptor (TCR) loci, which

evroth@its.caltech.edu.

Author contributions: EVR wrote the manuscript.

Publisher's Disclaimer: This is a PDF file of an unedited manuscript that has been accepted for publication. As a service to our customers we are providing this early version of the manuscript. The manuscript will undergo copyediting, typesetting, and review of the resulting proof before it is published in its final form. Please note that during the production process errors may be discovered which could affect the content, and all legal disclaimers that apply to the journal pertain.

Conflicts of interest: the author declares no conflicts of interest. 
will enable them to work as T cells. T-lineage-affiliated transcription factors GATA-3 and TCF1 (encoded by Tcf7) are induced early in this process, but several waves of other T-cell transcription factors are activated at distinct stages during and after commitment. Stages of this process in mouse development (ETP, DN2a, DN2b, DN3a, DN3b, DP) are defined in Fig. 1A and have similar counterparts in human development. The $\mathrm{T}$ cell precursors enter the thymus as multipotent cells that can develop into other cell types if their Notch signaling is blocked or interrupted. Between DN2a and DN2b stage, however, they lose this alternative developmental capacity, and they become intrinsically committed to generate $\mathrm{T}$ cells or die [6-8]. Commitment is an indicator of a major transition in gene regulatory network state as well as genome-wide epigenetic state.

Regulatory gene expression changes provide robust landmarks for the T-cell specification process [4](Fig. 1B). Recent single-cell transcriptome analysis confirms that the same ETP cells that initiate the T-cell program begin by expressing multiple progenitor-specific factors [9]. Progenitor-factor silencing can then be directly linked with the narrowing of developmental potential, since after commitment, addback of a progenitor factor like PU.1 can restore access to alternative developmental fates [10-12](rev. in [13]). Perturbation tests can be done relatively easily in early T-cell development because of excellent stromal coculture-based systems that support early differentiation in vitro [14], and efficient transduction with retroviral vectors for gain of function, shRNA knockdown, and Cre or CRISPR-mediated deletion experiments.

Transcription factors with different expression patterns each contribute independently to the changing gene expression patterns in the cells. For example, PU.1 is downregulated during commitment, $\mathrm{Bcl} 11 \mathrm{~b}$ is upregulated during commitment, and $\mathrm{E}$ proteins are expressed consistently throughout (Fig. 1C). Yet when the genes that encode them are disrupted by stage-specific Cre- or Cas9-dependent knockouts [15-17], whole-transcriptome analyses show that these factors interact combinatorially in different ways on different target genes (Fig. 1D), for promotion of the T-cell fate or for suppression of some alternative fate(s).

\section{Topological T-cell gene regulatory network model}

Perturbation evidence has been used to construct a "bottom-up" gene regulatory network model for T-cell specification from multipotent precursors [18]. The network model captures available functional data, giving causal polarity, not simply correlations, with the goal to clarify how well available evidence explains T-cell developmental control. A newer version of the model (Fig. 2) has been improved by mapping of the genomic binding of key transcription factors at increasingly relevant developmental stages, new tests for the regulatory functionality of these sites, new genome-wide analyses of genes affected by gain and loss of factor function in relevant stages, and improved methods of causing potent, synchronous perturbations within relevant developmental intervals (references in Table 1) [15-17,19-22]. There remain issues: not all edges may be direct; functional linkages measured in one developmental state may not be the ones operating at a different state; direct transcription factor binding to a gene may not indicate function; and gain- and loss-offunction phenotypes may not agree due to regulator dosage sensitivities (detailed in [23]). Some crucial limitations are discussed below. However, the network model illustrates the 
dynamic logical relationships between several distinct groups of regulators that guide Tlineage specification.

\section{Regulator Groups}

Group A (Fig. 2, upper left; see inset) is Notch signaling, working on direct targets as a transcriptional coactivator. Signaling is triggered when the transmembrane Notch1 protein comes into contact with Notch ligands DLL4 or DLL1 provided in the thymic microenvironment (thymic epithelium). The response depends on the expression of Notch1 and transcription factor-coding gene $R b p j$ (CSL, Suppressor of Hairless) in lymphoid precursors. Notch-activated target genes include Hes1, encoding a repressor, and Nrarp, encoding a feedback inhibitor.

Group B (Fig. 2, upper right and Spi1; see inset) is a group of stem/progenitor regulatory genes, expressed in the earliest pro-T cells [4,9]. Many are implicated in self-renewal and also participate in certain non-T cell fates. Among their products, PU.1 (encoded by Spi1) has the strongest genomic signature, as its binding occupancy is most prevalent and its canonical target motif is most enriched across the genomic sites that are specifically active during pre-commitment stages $[16,19,21]$.

Group C (Fig. 2, middle right; see inset) encodes the core group of T-lineage-affiliated transcription factors activated directly or indirectly by Notch signaling, including TCF1 (Tcf7), GATA-3, and Bcl11b. Regulatory genes Tcf7 and Gata3 are activated in the earliest responses to Notch signaling, and are essential from the earliest stages [24-27], while $B c 111 b$, Ets 1 and others are activated later [4].

Group D (Fig. 2, lower left, see inset) centers on the genes encoding the E proteins, E2A (Tcf3) and HEB ( Tcf12), which are expressed continuously but participate in different transcription factor dimers. As E2A/HEB dimers, they regulate many T-cell genes postcommitment $[15,28]$. They can be neutralized by dimerization with Id2 and Id3, which totally block their DNA binding. E proteins regulate not only some of the same postcommitment genes as Bcl11b, but also some of the same pre-commitment genes as PU.1 (Fig. 1C), possibly reflecting their ability to participate in distinct complexes with additional dimerization partners, e.g. group B gene Lyl1 [29-31].

Group E gene-encoded factors (Fig. 2, middle; see inset) are also expressed at similar levels from prethymic multipotent progenitor stages throughout early T-cell development. These include Runx family factors, Myb, Gfi1, and Ikaros family factors, which can play indispensable roles without being lineage-instructive. Runx1 is particularly important for the gene expression impacts of group $\mathrm{C}$ regulators. It collaborates with group $\mathrm{C}$ factors (GATA-3 and probably TCF1)[32-34] to repress group B gene Spi1 (encoding PU.1) during commitment $[20,35,36]$. However, before commitment, it co-localizes with PU.1 and contributes to its activity [20]. Some of the latest insights into mechanisms making commitment so transformative show how factors in group E can have highly regulated and dynamic functions in T-cell development despite their modestly changing levels. 
Cells in the T-cell pathway also require stage-specific viability support from three cytokine receptors until successful TCR expression. Initially, Kit and Flt3 are both required. Flt3 is downregulated midway through the ETP stage, Kit declines during commitment, while upregulation of IL7R (encoded by II7r and constitutively expressed II2rg) sustains the cells from DN2a onward.

\section{Essential Intergroup Network Circuits}

Circuit 1: Notch signaling (group A) activates the T-cell affiliated regulatory genes (group C) in a positive feed-forward circuit. For a key subset of the group C genes, Tcf7 and Gata3, this begins while the multipotent progenitor-associated gene set is still actively expressed [26,27]. Another important node in this network, represented by $B c 111 b$, is activated later, as described below.

Circuit 2: Within the initial stages of T-cell development, Notch signaling also modulates the activity of PU.1 ("Notch-sens PU.1"), whereas high-level PU.1 may inhibit Notch signaling ("PU.1-sens Notch"). PU.1 has direct positive effects on a subset of other group B regulatory genes, including Bcl1 1a, Lmo2 and Mef2c $[12,16]$. Notch signaling focuses PU.1 activity on target genes associated with multipotent progenitor status (group B), rather than on target genes associated with an alternative myelomonocytic differentiation pathway [12], enabling PU.1 to support proliferation in early T-cell stages [37]. Notch may accomplish this by repressing C/EBP family members $[12,16]$ needed to collaborate with PU.1 for myeloid differentiation [38,39], possibly via the Notch-induced repressor Hes1 [40]. The mechanism through which PU.1 damps down Notch signaling is not clear yet. The balance between PU. 1 and Notch signals, sustained over multiple cell cycles, is one of the key distinctions of the early T-lineage regulatory state (Fig. 2 legend).

Circuit 3: Basic helix-loop-helix (bHLH) E proteins, E2A and HEB (encoded by Tcf3 and Tcf12), group D in the network, are crucial for B as well as $\mathrm{T}$ cell development, but they play key roles in activating $\mathrm{T}$ lineage-specific genes as well as B-T shared genes. Their own expression changes relatively little during T-cell specification, but their connectivities in the network are stage- and context-dependent. While contributing to group B gene expression, likely via complexes with Lyl1 and Lmo2 ("L/L/E"), they are also needed especially to sustain Notch1 expression itself (group A)[15,41], and they become dominant regulators of T-cell-specific genes like the invariant TCR components activated specifically during and after commitment. E protein activity particularly strongly distinguishes the T-cell pathway from the Innate Lymphoid Cell (ILC) differentiation pathways, and needs to be sustained in order to prevent diversion of the pro-T cells to an ILC pathway [42-44](see Box 1).

Although levels of expression of the E proteins themselves are not strongly affected by perturbations of the other network components, their activities are highly modulated by other, dynamically regulated network members. The most prominent $\mathrm{E}$ protein inhibitors are helix-loop-helix antagonists Id2 or Id3. Although not normally expressed, Id 2 is potentially activatable in DN T-cell precursors under various growth-stimulatory conditions. Id3 is activated specifically by signals like those delivered by newly assembled TCR, which normally terminate the T-lineage determination process at the end of the DN3 stage. 
Importantly for the T-cell developmental process, regulators of three other network groups can work to block Id protein expression: PU.1 (group B)[16,37], Bcl11b (late-activated member of group C)[17], and possibly Notch signals (group A)[12,44], themselves. Thus, E protein activity may be seen to be protected through a stage-to-stage relay mechanism for inhibiting its inhibitors.

\section{Latent circuits, suppressed in normal development}

Three powerful circuits for diversion to alternative lineages are maintained in latent form in pro-T cells (details in Box 1). All of these are normally kept in check during normal early Tcell development but become fully active in case of regulatory perturbations. (1) Elevated PU.1, when combined with loss of Notch signal effectiveness at any stage through DN3, causes coordinated, fast multi-node inhibition of the T-cell program coupled with induction of a monocytic or dendritic-cell-like program. (2) Elevated GATA-3 at any stage through DN2 causes the T-cell program to abort, with cells favoring a transition to the mast-cell program. (3) Removal of Bcl11b at any time up through DN3 stage causes cells to redirect to an abnormal T-cell program with strong innate lymphoid cell-like features. Because of the large numbers of regulatory genes affected in these latent circuits, there may be many indirect and cooperative effects involved (Box 1).

\section{Commitment}

Commitment is the transition when developing pro-T cells lose the intrinsic ability to shift to an alternative (non-T) fate if Notch stimuli are withdrawn. Fluorescent reporter assays show that at the single-cell level commitment occurs when cells upregulate $B c 111 b$ [6]. It is also accompanied by the decline in expression of PU.1 and multiple other group B regulators, and closely followed or accompanied by upregulation of other late-tier group $\mathrm{C}$ factor coding genes, Ets1, Ets2, and Lef1 (Fig. 1B,C and [4]). Thus, the metastable network state dominated by Group B factors, together with Notch (group A) and Group E contributions, gives way to the alternative, committed network state dominated by Group $\mathrm{C}$ factors, together with Notch, Group E, and full-fledged Group D contributions. Recent genome-wide evidence shows that this is when chromatin sites enriched for PU.1 binding motifs close and chromatin sites enriched for E protein and TCF1 binding motifs open [16,19,21]. This transformation also entails a global transformation of 3D chromatin organization [19]. Thousands of genomic sites gain accessibility while thousands lose accessibility, while looping frequencies within topologically-associated domains undergo considerable changes. Whole topologically associated domains undergo compartment flips, from decondensed, "active" configurations to condensed, "silenced" configurations [19].

\section{Network dynamics: beyond network topology}

Despite the intricacy of the documented network connections, the topological network model is not sufficient to explain the dynamics of the T-cell development process. The main problems are that in actual thymocytes of young adult mice, the state changes are slow, occupying days and multiple cell divisions, and that individual regulatory nodes exhibit unpredictably delayed responses to changes in known positive or negative inputs. Most obviously, the commitment transition occurs later than it would be predicted to occur based 
on simple assumptions about gene regulation biochemistry. For example, $B c 111 b$ is turned on by Notch signaling, Runx, GATA-3, and TCF-1, but all of these positive inputs are already strongly active, days before $B c 111 b$ is turned on [6]. Similarly, GATA-3, TCF-1 and Runx1 can repress Spi1 [32-36], even though Spi1 expression persists in the presence of these factors for many cell cycles before commitment. In these respects, the T-cell regulatory network starkly differs from other classic models, like the Boolean model of sea urchin endomesoderm specification [45] or ODE models of Drosophila syncytial blastoderm patterning by gap genes [46].

Several possible reasons could contribute. The T-cell network model is certainly incomplete, and the known regulators could be opposed by trans-acting antagonists at crucial target nodes, as yet uncharacterized. T-cell development also shows a narrow optimum dosage range in its responses to several of its key regulators, shown conspicuously for effects of GATA-3 [33,34,47,48] but also for E proteins [49] and Runx1 [50]. This could reflect a need to keep a regulator's dosage low enough to avoid activation of confounding circuits while keeping it high enough to out-compete possible sources of antagonism. More profoundly, however, there may be a problem with the basic assumption of topological gene network models: namely, the assumption that when a transcription factor is expressed, it will "find" its target sites on the genome in a predictable way. There are at least two issues with this assumption in the T-cell case, discussed in the next sections. One is that T-cell development starts from an epigenetic state that imposes real barriers to transcription factor activity on the network genes. The other is that even when sites are accessible, the deployment of transcription factors across possible sites is not autonomously determined, but influenced strongly by other factors. This creates novel forms of indirect antagonism as well as cooperativity, but with rules yet to be characterized. Together, these are formidable sources of nonlinearity in network state dynamics.

\section{Accessibility}

Several factors with important roles in the T-cell specification network model are known to be able to open chromatin. PU.1 (group B)[16,51,52] and TCF-1 (early-initiating group C) [21] can displace nucleosomes, create nuclease accessibility, and initiate activating histone modifications around their binding sites. Chromatin opening is probably an important aspect of their mechanisms of action as positive transcriptional regulators. However, not all their genomic sites are equally accessible to them in any given cell state. For example, PU.1 has been compared by ChIP-seq in various cellular lineages and across different levels of expression within the same cell lineage, where collaborating factors are more likely to be similar [16,52,53]. In pro-T cells as in other cell types [54,55], PU.1 is excluded from chromatin with H3K27me3 histone modifications, even from sites that are highly bound by PU.1 in B or myeloid cells [53], but otherwise it binds to approximately equal numbers of "open" and "closed" sites in pro-T cells, as classified by ATAC accessibility [16]. This ability to bind closed sites is consistent with its "pioneer factor" role in other cells, albeit showing that binding is not always sufficient to cause opening. But quantitative analysis shows that PU.1 only occupies closed sites if they have substantially better matches to the ideal PU.1 target motif than is needed for open sites [16]. Thus, even for a "pioneer factor" like PU.1, the impact of prior site opening can be considerable. 
Chromatin state not only affects transcription factor binding, but can also affect the timing of changes in target gene expression once transcription factor binding occurs. A striking, although possibly extreme, example is in the regulation of $B c 111 \mathrm{~b}$. The four known positive inputs for $B c 111 b$, namely GATA-3, TCF1, Runx1, and Notch signaling [6], are all active within ETP stage $[53,56]$. However, $B c 111 b$ itself is only turned on in late DN2a stage, measurably multiple days and cell cycles after the ETP to DN2a transition [6]. At least part of the delay has now been shown to be based on a cis-acting epigenetic constraint. Despite some local DNase accessibility, permissive histone marks, and PU.1 binding at the $B c 111 b$ superenhancer region as early as ETP stage [19,53,57], even accompanied by lincRNA transcripts [58], the whole chromatin subdomain from $B c 111 b$ to $V r k 1$ has a closed configuration in ETP and most DN2a cells [19]. Bcl1 $1 b$ may also require escape from a nuclear matrix-associated compartment to be activated [58]. Its initial state is evidently a substantial kinetic barrier to the activation of the locus. This has been shown by tagging the two alleles of $B c 111 b$ in the same mouse with two different fluorescent protein reporters [59]. A trans-acting constraint, whatever it was, would affect activation of both alleles equally, whereas if the two alleles were unsynchronized in their activation in the same cell, this would need to be explained by a cis-acting constraint. In fact, longitudinal imaging of individual clones shows that multiple cell cycles can intervene between expression of the first and second-activated alleles within the same cells [59]. As allele choice in a clone is random, the same epigenetic resistance that is measured by the difference in allele activation times would likely have slowed the response of the first allele as well. Thus, the real biological system is both slower and more stochastically noisy than the topological model, or an ODE implementation of the topological model, might predict.

\section{Nonautonomous transcription factor "choreography"}

Durable epigenetic states can establish barriers to interconversion between cell types as just described. However, ChIP-seq analyses show that many factors also redistribute their binding patterns over the genome during natural development, relatively quickly and within a cell lineage. GATA-3 occupies markedly different site patterns at different pro-T cell [53] and later T-cell stages [60]. Runx1, like GATA-3, shifts its binding sites markedly during normal pro-T cell development as cells progress through the commitment transition [20], with many sites vacated despite overall increases in total binding. Are the losses of GATA-3 or Runx1 binding due to loss of co-occupying factors, which might be represented in a gene network model as AND logic partners? Are the losses due to displacement by competing antagonists, which might be represented as AND NOT inputs? Or could something else be occurring?

Collaboration with other factors in normal T-cell development both positively and negatively influences the site choices of specific transcription factors. In fact, signs of this phenomenon have been seen widely (e.g. [61-64]) and may be a general principle of developmental state shifts. In pre-commitment stages, PU.1 strongly recruits other factors to bind with it at its target sites, including Runx1, Satb1, and GATA-3 [20]. In later T-cell development (DP stage), TCF1 is a strong influence on other factors, including E proteins [21,22]. Gene network impacts of TCF1 in DP cells also cause it to stabilize E proteins, complicating this effect [22]. However, without changing TCF1 levels, the E protein HEB also influences the 
sites where TCF1 binds to the DNA [22]. Importantly, both for the effect of PU.1 and for the effect of HEB, partner recruitment to co-binding sites can also draw partners competitively away from alternative sites ("coregulator theft")[20]. When a cell line similar to newly committed pro-T cells (PU.1-negative) is transduced to (re-)express PU.1, mimicking retrograde differentiation, Runx1, Satb1, and GATA-3 move to different sites, vacating many while joining PU.1 at others. This effect is not "eviction", for it does not appear to involve any PU.1 binding at the emptied sites [20]. The response is relevant to normal development, for the shifts of Runx1 binding that PU.1 causes in the artificial retrograde differentiation response are largely the reverse of the natural shifts of Runx1 that occur during normal forward differentiation, as endogenous PU.1 is turned off. Motif analysis shows that reintroduced PU.1 in the cell line model draws Runx1 to combined sites that are "poorerquality" Runx sites, based on Runx motif scores, than those that Runx1 occupies in the absence of PU.1 [20]. This too mirrors the natural deployment changes of Runx1 from precommitment to post-commitment stages.

Transcription factor pool effects like these emphasize that the physiologically regulated pool sizes of these factors are limited, so that there is competition for these factors among distinct sets of potentially accessible sites. Thus, the ability of genomic sequence at a site to predict the likelihood of occupancy by a given factor depends not only on the site's match to an optimal motif and its accessibility in chromatin, but also on the presence of specific other "theft-capable" factors in the cell that may nucleate more stable ternary complexes, in the context of the pool size of the factor of interest. Although probably important for predicting gene network dynamics, at present the key parameters are hard to measure. We do not yet know the rules determining which factors are "theft-capable" or "theft-vulnerable" in different contexts. Proteomics of transcription factor complex assembly must become much more sensitive, to capture and measure these interactions in a genomic site-specific way.

\section{Concluding remarks}

Gene network logic in early embryos is extremely powerful not only to describe but also to predict developmental dynamics, partly because of the orderly increase in complexity from the unique state of the fertilized egg, and partly because of the epigenetic openness of the system. Not only does the genome act as though it is functionally unconstrained during zygotic gene activation, but also pre-existing transcriptional regulators are sparse. In contrast, $\mathrm{T}$ cells in young adult mice develop from non-naïve stem and progenitor cells that have fully established tissue-specific epigenetic constraints already, and harbor a rich complement of stem and progenitor-associated transcription factors already investing the genome. From this point of view, natural $\mathrm{T}$ cell development is more like induced pluripotent cell reprogramming than like emergence of an original embryonic cell lineage.

Here, the current understanding of gene network modules that guide progenitors to acquire T-cell identity is reviewed. Activities of these modules, containing nodes encoding transcription factors, are seen to cooperate and compete in shifting circuitries. However, the powerful experimental systems available for early T-cell development reveal that the transfactors encoded by nodes in the network currently provide only a qualitative understanding of the dynamics of T-cell developmental progression. The relationships between factor 
action and chromatin opening still need to be factored in, not omitting their intrinsic stochasticity. Furthermore, highly nonlinear system behavior emerges because of the unexpectedly strong system-level effects of transcription factor collaboration given limited pool sizes. Technologies that measure these interactions accurately will make a whole new generation of gene network models possible.

\section{Acknowledgments}

I am indebted to William J. R. Longabaugh for partnership in developing the 2017 version of the gene network model, and to Michael B. Elowitz, Carsten Peterson, Denis Thieffry, Hao Yuan Kueh, Hiroyuki Hosokawa, Jonas Ungerbäck, Mary A. Yui, and the late Eric H. Davidson for discussions that shaped the perspectives presented here. I apologize to many colleagues whose work was not cited in this short review. Relevant work in the author's lab has been supported by USPHS grants R01AI095943, R01AI135200, R01HD076915, and R01HL119102, and I gratefully acknowledge support from the Albert Billings Ruddock Professorship of Biology.

\section{REFERENCES}

[1]. Schmitt TM, Ciofani M, Petrie HT, Zúñiga-Pflücker JC: Maintenance of T cell specification and differentiation requires recurrent Notch receptor-ligand interactions. J. Exp. Med 2004; 200:469_ 479. [PubMed: 15314075]

[2]. Seo W, Taniuchi I: Transcriptional regulation of early T-cell development in the thymus. Eur J Immunol 2016; 46:531-8. [PubMed: 26763078]

[3]. De Obaldia ME, Bhandoola A: Transcriptional regulation of innate and adaptive lymphocyte lineages. Annu Rev Immunol 2015; 33:607-42. [PubMed: 25665079]

[4]. Yui MA, Rothenberg EV: Developmental gene networks: a triathlon on the course to T cell identity. Nat Rev Immunol 2014; 14:529-45. [PubMed: 25060579]

[5]. Thompson PK, Zúñiga-Pflücker JC: On becoming a T cell, a convergence of factors kick it up a Notch along the way. Semin Immunol 2011; 23:350-9. [PubMed: 21981947]

[6]. Kueh HY, Yui MA, Ng KKH, Pease SS, Zhang JA, Damle SS, Freedman G, Siu S, Bernstein ID, Elowitz MB et al.: Asynchronous combinatorial action of four regulatory factors activates $B c 111 b$ for T cell commitment. Nat Immunol 2016; 17:956-965. [PubMed: 27376470]

[7]. Yui MA, Feng N, Rothenberg EV: Fine-scale staging of T cell lineage commitment in adult mouse thymus. J Immunol 2010; 185:284-93. [PubMed: 20543111]

[8]. Masuda K, Kakugawa K, Nakayama T, Minato M, Katsura Y, Kawamoto H: T cell lineage determination precedes the initiation of TCR $\beta$ rearrangement. J Immunol 2007; 179:3699-3706. [PubMed: 17785806]

*[9]. Zhou W, Yui MA, Williams BA, Yun J, Wold BJ, Cai L, Rothenberg EV: Single-cell analysis reveals regulatory gene expression dynamics leading to lineage commitment in early $\mathrm{T}$ cell development. Cell Syst 2019; 9:321-337 e9. [PubMed: 31629685] Single-cell RNA analysis dissects the underlying gene expression changes from the earliest mouse ETP stages through Tcell lineage commitment. By using a combination of transcriptome analysis methods including multiplex single-molecule fluorescence in situ hybridization, the T-cell program is shown to initiate in cells still actively sustaining the progenitor regulatory program. Successive regulatory states along the earliest steps in the T-cell pathway are confirmed by single-cell in vitro analyses of T-lineage precursor frequencies, differentiation kinetics, and plasticity.

[10]. Lefebvre JM, Haks MC, Carleton MO, Rhodes M, Sinnathamby G, Simon MC, Eisenlohr LC, Garrett-Sinha LA, Wiest DL: Enforced expression of Spi-B reverses T lineage commitment and blocks $\beta$-selection. J Immunol 2005; 174:6184-94. [PubMed: 15879115]

[11]. Laiosa CV, Stadtfeld M, Xie H, de Andres-Aguayo L, Graf T: Reprogramming of committed T cell progenitors to macrophages and dendritic cells by C/EBPa and PU.1 transcription factors. Immunity 2006; 25:731-44. [PubMed: 17088084]

[12]. Del Real MM, Rothenberg EV: Architecture of a lymphomyeloid developmental switch controlled by PU.1, Notch and Gata3. Development 2013; 140:1207-19. [PubMed: 23444353] 
[13]. Rothenberg EV, Hosokawa H, Ungerback J: Mechanisms of Action of Hematopoietic Transcription Factor PU.1 in Initiation of T-Cell Development. Front Immunol 2019; 10:228. [PubMed: 30842770]

[14]. Schmitt TM, Zúñiga-Pflücker JC: Induction of T cell development from hematopoietic progenitor cells by Delta-like-1 in vitro. Immunity 2002; 17:749-56. [PubMed: 12479821]

*[15]. Miyazaki M, Miyazaki K, Chen K, Jin Y, Turner J, Moore AJ, Saito R, Yoshida K, Ogawa S, Rodewald HR et al.: The E-Id Protein Axis Specifies Adaptive Lymphoid Cell Identity and Suppresses Thymic Innate Lymphoid Cell Development. Immunity 2017; 46:818-834 e4. [PubMed: 28514688] In a comprehensive study of the antagonistic effects of E proteins and Id2, genome-wide analysis of fetal thymocytes in E protein deficient (Tcf3, Tcf12 double knockout) mice reveals the full scope of $E$ protein activities in $T$ cell development and in antagonism of latent innate-cell potential. Like loss of E proteins, inducible expression of an Id 2 transgene is shown to unleash the innate-cell program in thymocytes (also see refs. *42, *43).

*[16]. Ungerbäck J, Hosokawa H, Wang X, Strid T, Williams BA, Sigvardsson M, Rothenberg EV: Pioneering, chromatin remodeling, and epigenetic constraint in early T-cell gene regulation by SPI1 (PU.1). Genome Res 2018; 28:1508-1519. [PubMed: 30171019] A detailed analysis of PU. 1 binding to distinct classes of genomic sites in early $\mathrm{T}$ cells measures effects of motif quality, site accessibility, and enhancer vs. promoter site location in determining functional gene expression responses. Effects of site affinity are separated functionally from effects of site accessibility by requirement for specific PU.1 protein domains to enable binding.

*[17]. Hosokawa H, Romero-Wolf M, Yui MA, Ungerbäck J, Quiloan MLG, Matsumoto M, Nakayama KI, Tanaka T, Rothenberg EV: Bcl11b sets pro-T cell fate by site-specific cofactor recruitment and by repressing Id2 and Zbtb16. Nat Immunol 2018; 19:1427-1440. [PubMed: 30374131] Mechanisms of Bcl11b action in commitment are shown to result from direct effects as a site-specific nucleator of specific chromatin-modifying complexes and also from indirect gene network effects via repression of $I d 2$. Runx1 is also shown to be a key partner in the direct positive and negative actions of Bcl11b. Earlier results defining the target genes of Bcl11b are shown in ref. $* 18$.

*[18]. Longabaugh WJR, Zeng W, Zhang JA, Hosokawa H, Jansen CS, Li L, Romero-Wolf M, Liu P, Kueh HY, Mortazavi A et al.: Bcl11b and combinatorial resolution of cell fate in the T-cell gene regulatory network. Proc Natl Acad Sci U S A 2017; 114:5800-5807. [PubMed: 28584128] Transcriptome analysis of Bcl11b perturbation in dynamic pro-T cell development identifies many of the targets of Bcl11b and provides a strong indication of the regulatory overlap between $\mathrm{Bcl} 11 \mathrm{~b}$ and E protein effects. The $B c 111 b$ knockout phenotype is shown to be a diversion to a program with progenitor and innate-like aspects distinct from the effects of $B c 111 b$ disruption in later T cells. As a background to analyze the role of Bcl11b in commitment, this paper presents the basic gene regulatory network model that is updated here, with a complete discussion of its rationale presented as a supplementary text.

*[19]. Hu G, Cui K, Fang D, Hirose S, Wang X, Wangsa D, Jin W, Ried T, Liu P, Zhu J et al.: Transformation of accessible chromatin and 3D nucleome underlies lineage commitment of early T cells. Immunity 2018; 48:227-242 e8. [PubMed: 29466755] A multi-level analysis of DNase sensitivity, topologically associated domain structures, and compartment dynamics of T-cell development from prethymic stages through to the DP stage reveals the magnitude of the 3-D nucleome transformations during commitment, the prevalence of PU.1 before commitment, and the potent architectural role of Bcl11b after commitment.

*[20]. Hosokawa H, Ungerbäck J, Wang X, Matsumoto M, Nakayama KI, Cohen SM, Tanaka T, Rothenberg EV: Transcription factor PU.1 represses and activates gene expression in early T cells by redirecting partner transcription factor binding. Immunity 2018; 48:1119-1134.e7. [PubMed: 29924977] PU.1 protein complexes in pro-T cells contain Runx 1 and Satb1, and when PU.1 is introduced into late pro-T cells, PU.1 causes extensive redistribution of Runx1 and Satb1 occupancy sites over the genome. Motif analysis shows that high-quality Runx 1 sites can lose Runx1 binding as PU.1 recruits Runx1 to alternative ternary complex sites, sites which Runx1 normally occupies in pro-T cells only before commitment. Transcriptional responses also suggest that the redeployment of Runx1 is functionally involved in repressive effects of PU.1.

*[21]. Johnson JL, Georgakilas G, Petrovic J, Kurachi M, Cai S, Harly C, Pear WS, Bhandoola A, Wherry EJ, Vahedi G: Lineage-Determining Transcription Factor TCF-1 Initiates the Epigenetic 
Identity of T Cells. Immunity 2018; 48:243-257 e10. [PubMed: 29466756] TCF-1 motifs are shown to predominate in regulatory elements that are opened definitively during T-cell commitment and sustained afterwards, and detailed analysis of DP cells shows the ability of TCF-1 to alter chromatin configuration. Even when introduced into fibroblasts, TCF-1 is shown to open many T-lineage specific chromatin sites and to induce detectable transcription of T-cell specific genes.

*[22]. Emmanuel AO, Arnovitz S, Haghi L, Mathur PS, Mondal S, Quandt J, Okoreeh MK, Maienschein-Cline M, Khazaie K, Dose M et al.: TCF-1 and HEB cooperate to establish the epigenetic and transcription profiles of $\mathrm{CD}^{+}{ }^{+} \mathrm{CD} 8^{+}$thymocytes. Nat Immunol 2018; 19:13661378. [PubMed: 30420627] In studies focusing on DP stage cells, TCF-1 and HEB are shown to affect each other's occupancy patterns and the states of chromatin at their sites, consistent with the similar phenotypes of Tcf7 and Tcf 12 knockouts at this stage. TCF-1 site choice is affected by HEB without alteration of the total level of TCF-1, but HEB overall levels are strongly affected by the presence of TCF-1, through a mechanism involving Notch-dependent HEB degradation and the requirement for TCF-1 to inhibit Notch signaling.

[23]. Rothenberg EV: Causal Gene Regulatory Network Modeling and Genomics: Second-Generation Challenges. J Comput Biol 2019; 26:703-718. [PubMed: 31063008]

[24]. Hattori N, Kawamoto H, Fujimoto S, Kuno K, Katsura Y: Involvement of transcription factors TCF-1 and GATA-3 in the initiation of the earliest step of T cell development in the thymus. J Exp Med 1996; 184:1137-47. [PubMed: 9064330]

[25]. Hosoya T, Kuroha T, Moriguchi T, Cummings D, Maillard I, Lim KC, Engel JD: GATA-3 is required for early T lineage progenitor development. J Exp Med 2009; 206:2987-3000. [PubMed: 19934022]

[26]. Germar K, Dose M, Konstantinou T, Zhang J, Wang H, Lobry C, Arnett KL, Blacklow SC, Aifantis I, Aster JC et al.: T-cell factor 1 is a gatekeeper for T-cell specification in response to Notch signaling. Proc Natl Acad Sci U S A 2011; 108:20060-5. [PubMed: 22109558]

[27]. Weber BN, Chi AW, Chavez A, Yashiro-Ohtani Y, Yang Q, Shestova O, Bhandoola A: A critical role for TCF-1 in T-lineage specification and differentiation. Nature 2011; 476:63-8. [PubMed: 21814277]

[28]. Miyazaki M, Rivera RR, Miyazaki K, Lin YC, Agata Y, Murre C: The opposing roles of the transcription factor E2A and its antagonist Id3 that orchestrate and enforce the naive fate of T cells. Nat Immunol 2011; 12:992-1001. [PubMed: 21857655]

[29]. Zohren F, Souroullas GP, Luo M, Gerdemann U, Imperato MR, Wilson NK, Göttgens B, Lukov GL, Goodell MA: The transcription factor Lyl-1 regulates lymphoid specification and the maintenance of early T lineage progenitors. Nat Immunol 2012; 13:761-9. [PubMed: 22772404]

[30]. Zhong Y, Jiang L, Hiai H, Toyokuni S, Yamada Y: Overexpression of a transcription factor LYL1 induces T- and B-cell lymphoma in mice. Oncogene 2007; 26:6937-6947. [PubMed: 17486074]

[31]. Barndt RJ, Dai M, Zhuang Y: Functions of E2A-HEB heterodimers in T-cell development revealed by a dominant negative mutation of HEB. Mol Cell Biol 2000; 20:6677-6685. [PubMed: 10958665]

[32]. Rosenbauer F, Owens BM, Yu L, Tumang JR, Steidl U, Kutok JL, Clayton LK, Wagner K, Scheller M, Iwasaki H et al.: Lymphoid cell growth and transformation are suppressed by a key regulatory element of the gene encoding PU.1. Nat Genet 2006; 38:27-37. [PubMed: 16311598]

[33]. Taghon T, Yui MA, Rothenberg EV: Mast cell lineage diversion of T lineage precursors by the essential T cell transcription factor GATA-3. Nat Immunol 2007; 8:845-55. [PubMed: 17603486]

[34]. Scripture-Adams DD, Damle SS, Li L, Elihu KJ, Qin S, Arias AM, Butler RR 3rd, Champhekar A, Zhang JA, Rothenberg EV: GATA-3 dose-dependent checkpoints in early T cell commitment. J Immunol 2014; 193:3470-91. [PubMed: 25172496]

[35]. Huang G, Zhang P, Hirai H, Elf S, Yan X, Chen Z, Koschmieder S, Okuno Y, Dayaram T, Growney JD et al.: PU.1 is a major downstream target of AML1 (RUNX1) in adult mouse hematopoiesis. Nat Genet 2008; 40:51-60. [PubMed: 17994017]

[36]. Zarnegar MA, Chen J, Rothenberg EV: Cell-type-specific activation and repression of PU.1 by a complex of discrete, functionally specialized cis-regulatory elements. Mol Cell Biol 2010; 30:4922-39. [PubMed: 20696839] 
[37]. Champhekar A, Damle SS, Freedman G, Carotta S, Nutt SL, Rothenberg EV: Regulation of early T-lineage gene expression and developmental progression by the progenitor cell transcription factor PU.1. Genes Dev 2015; 29:832-48. [PubMed: 25846797]

[38]. Feng R, Desbordes SC, Xie H, Tillo ES, Pixley F, Stanley ER, Graf T: PU.1 and C/EBPa/ $\beta$ convert fibroblasts into macrophage-like cells. Proc. Natl. Acad. Sci. U.S.A 2008; 105:60576062. [PubMed: 18424555]

[39]. Friedman AD: Transcriptional control of granulocyte and monocyte development. Oncogene 2007; 26:6816-6828. [PubMed: 17934488]

[40]. De Obaldia ME, Bell JJ, Wang X, Harly C, Yashiro-Ohtani Y, Delong JH, Zlotoff DA, Sultana DA, Pear WS, Bhandoola A: T cell development requires constraint of the myeloid regulator C/ EBP-a by the Notch target and transcriptional repressor Hes1. Nat Immunol 2013; 14:1277-84. [PubMed: 24185616]

[41]. Yashiro-Ohtani Y, He Y, Ohtani T, Jones ME, Shestova O, Xu L, Fang TC, Chiang MY, Intlekofer AM, Blacklow SC et al.: Pre-TCR signaling inactivates Notch1 transcription by antagonizing E2A. Genes Dev 2009; 23:1665-76. [PubMed: 19605688]

*[42]. Zook EC, Li ZY, Xu Y, de Pooter RF, Verykokakis M, Beaulieu A, Lasorella A, MaienscheinCline M, Sun JC, Sigvardsson M et al.: Transcription factor ID2 prevents E proteins from enforcing a naive T lymphocyte gene program during NK cell development. Sci Immunol 2018; 3.

*[43]. Wang HC, Qian L, Zhao Y, Mengarelli J, Adrianto I, Montgomery CG, Urban JF Jr., Fung KM, Sun XH: Downregulation of E Protein Activity Augments an ILC2 Differentiation Program in the Thymus. J Immunol 2017; 198:3149-3156. [PubMed: 28258196] With ref. *18, refs. *42 and *43 show that the antagonism between E proteins and Id factors is the main or sole barrier separating the T-cell program from an innate lymphoid cell program, both within the thymus and within NK cell development. This emphasizes the profound regulatory similarity between these programs in other respects.

[44]. Chea S, Schmutz S, Berthault C, Perchet T, Petit M, Burlen-Defranoux O, Goldrath AW, Rodewald HR, Cumano A, Golub R: Single-Cell Gene Expression Analyses Reveal Heterogeneous Responsiveness of Fetal Innate Lymphoid Progenitors to Notch Signaling. Cell Rep 2016; 14:1500-1516. [PubMed: 26832410]

[45]. Peter IS, Faure E, Davidson EH: Predictive computation of genomic logic processing functions in embryonic development. Proc Natl Acad Sci U S A 2012; 109:16434-42. [PubMed: 22927416]

[46]. Verd B, Crombach A, Jaeger J: Dynamic maternal gradients control timing and shift-rates for Drosophila gap gene expression. PLoS Comput Biol 2017; 13:e1005285. [PubMed: 28158178]

[47]. Xu W, Carr T, Ramirez K, McGregor S, Sigvardsson M, Kee BL: E2A transcription factors limit expression of Gata3 to facilitate T lymphocyte lineage commitment. Blood 2013; 121:1534-42. [PubMed: 23297135]

[48]. García-Ojeda ME, Klein Wolterink RG, Lemaître F, Richard-Le Goff O, Hasan M, Hendriks RW, Cumano A, Di Santo JP: GATA-3 promotes T cell specification by repressing B cell potential in pro-T cells. Blood 2013; 121:1749-59. [PubMed: 23287858]

[49]. Wang D, Claus CL, Vaccarelli G, Braunstein M, Schmitt TM, Zuniga-Pflucker JC, Rothenberg EV, Anderson MK: The basic helix-loop-helix transcription factor HEBAlt is expressed in pro-T cells and enhances the generation of T cell precursors. J Immunol 2006; 177:109-19. [PubMed: 16785505]

[50]. Wong WF, Nakazato M, Watanabe T, Kohu K, Ogata T, Yoshida N, Sotomaru Y, Ito M, Araki K, Telfer J et al.: Over-expression of Runx1 transcription factor impairs the development of thymocytes from the double-negative to double-positive stages. Immunology 2010; 130:243-53. [PubMed: 20102410]

[51]. Barozzi I, Simonatto M, Bonifacio S, Yang L, Rohs R, Ghisletti S, Natoli G: Coregulation of transcription factor binding and nucleosome occupancy through DNA features of mammalian enhancers. Mol Cell 2014; 54:844-57. [PubMed: 24813947]

[52]. Heinz S, Benner C, Spann N, Bertolino E, Lin YC, Laslo P, Cheng JX, Murre C, Singh H, Glass CK: Simple combinations of lineage-determining transcription factors prime cis-regulatory elements required for macrophage and B cell identities. Mol Cell 2010; 38:576-89. [PubMed: 20513432] 
[53]. Zhang JA, Mortazavi A, Williams BA, Wold BJ, Rothenberg EV: Dynamic transformations of genome-wide epigenetic marking and transcriptional control establish T cell identity. Cell 2012; 149:467-82. [PubMed: 22500808]

[54]. Petruk S, Mariani SA, De Dominici M, Porazzi P, Minieri V, Cai J, Iacovitti L, Flomenberg N, Calabretta B, Mazo A: Structure of Nascent Chromatin Is Essential for Hematopoietic Lineage Specification. Cell Rep 2017; 19:295-306. [PubMed: 28402853]

[55]. Wu R, Nie Q, Tapper EE, Jerde CR, Dunlap GS, Shrestha S, Elraiyah TA, Offer SM, Diasio RB: Histone H3K27 Trimethylation Modulates 5-Fluorouracil Resistance by Inhibiting PU.1 Binding to the DPYD Promoter. Cancer Res 2016; 76:6362-6373. [PubMed: 27578004]

[56]. Mingueneau M, Kreslavsky T, Gray D, Heng T, Cruse R, Ericson J, Bendall S, Spitzer MH, Nolan GP, Kobayashi K et al.: The transcriptional landscape of a $\beta$ T cell differentiation. Nat Immunol 2013; 14:619-32. [PubMed: 23644507]

[57]. Yoshida H, Lareau CA, Ramirez RN, Rose SA, Maier B, Wroblewska A, Desland F, Chudnovskiy A, Mortha A, Dominguez C et al.: The cis-Regulatory Atlas of the Mouse Immune System. Cell 2019; 176:897-912 e20. [PubMed: 30686579]

*[58]. Isoda T, Moore AJ, He Z, Chandra V, Aida M, Denholtz M, Piet van Hamburg J, Fisch KM, Chang AN, Fahl SP et al.: Non-coding Transcription Instructs Chromatin Folding and Compartmentalization to Dictate Enhancer-Promoter Communication and T Cell Fate. Cell 2017; 171:103-119 e18. [PubMed: 28938112] The $B c 111 b$ gene superenhancer region is shown to be the template for transcription of a developmentally regulated lncRNA, "ThymoD". Transcription from the ThymoD/superenhancer region is shown to be important in cis for the activation of the $B c 111 b$ gene and to enable a silent $B c 111 b$ gene to relocate from the nuclear matrix to the nuclear interior, where it becomes active. Also see ref. $* 59$ for evidence of cis-acting mechanisms controlling Bcl11 b activation.

*[59]. Ng KKH, Yui MA, Mehta A, Siu S, Irwin B, Pease S, Hirose S, Elowitz MB, Rothenberg EV, Kueh HY: A stochastic epigenetic switch controls the dynamics of T-cell lineage commitment. eLife 2018; 7:e37851. [PubMed: 30457103] In a mouse strain with different fluorescent reporter coding sequences inserted into the two alleles of $B c 111 b$, thymocyte subsets developing in vivo and differentiating in vitro reveal that individual cells may activate the two alleles at different times relative to one another. Longitudinal imaging and mathematical modeling implicate a tenacious cis-acting constraint for activation timing. One element of the $B c 111 b$ superenhancer is shown to be critical for the earliest phase of activation, and results indicate a developmentally limited window of opportunity for locus activation. Also see ref. $* 58$ for evidence of cis-acting mechanisms for $B c 111 b$ activation.

[60]. Wei G, Abraham BJ, Yagi R, Jothi R, Cui K, Sharma S, Narlikar L, Northrup DL, Tang Q, Paul WE et al.: Genome-wide analyses of transcription factor GATA3-mediated gene regulation in distinct T cell types. Immunity 2011; 35:299-311. [PubMed: 21867929]

[61]. Lin YC, Jhunjhunwala S, Benner C, Heinz S, Welinder E, Mansson R, Sigvardsson M, Hagman J, Espinoza CA, Dutkowski J et al.: A global network of transcription factors, involving E2A, EBF1 and Foxo1, that orchestrates B cell fate. Nat. Immunol 2010; 11:635-643. [PubMed: 20543837]

[62]. Evans CM, Jenner RG: Transcription factor interplay in T helper cell differentiation. Brief Funct Genomics 2013; 12:499-511. [PubMed: 23878131]

[63]. Chronis C, Fiziev P, Papp B, Butz S, Bonora G, Sabri S, Ernst J, Plath K: Cooperative binding of transcription factors orchestrates reprogramming. Cell 2017; 168:442-459. [PubMed: 28111071]

[64]. Sieweke MH, Graf T: A transcription factor party during blood cell differentiation. Curr. Opin. Genet. Devel 1998; 8:545-551. [PubMed: 9794826]

[65]. Belyaev NN, Biro J, Athanasakis D, Fernandez-Reyes D, Potocnik AJ: Global transcriptional analysis of primitive thymocytes reveals accelerated dynamics of $\mathrm{T}$ cell specification in fetal stages. Immunogenetics 2012; 64:591-604. [PubMed: 22581009]

[66]. Yu Y, Wang J, Khaled W, Burke S, Li P, Chen X, Yang W, Jenkins NA, Copeland NG, Zhang S et al.: Bcl11a is essential for lymphoid development and negatively regulates p53. J Exp Med 2012; 209:2467-83. [PubMed: 23230003] 
[67]. Li P, Burke S, Wang J, Chen X, Ortiz M, Lee SC, Lu D, Campos L, Goulding D, Ng BL et al.: Reprogramming of T cells to natural killer-like cells upon $B c 111 b$ deletion. Science 2010; 329:85-89. [PubMed: 20538915]

[68]. Kaech SM, Cui W: Transcriptional control of effector and memory CD8 ${ }^{+} \mathrm{T}$ cell differentiation. Nat Rev Immunol 2012; 12:749-61. [PubMed: 23080391]

[69]. Seillet C, Mielke LA, Amann-Zalcenstein DB, Su S, Gao J, Almeida FF, Shi W, Ritchie ME, Naik SH, Huntington ND et al.: Deciphering the Innate Lymphoid Cell transcriptional program. Cell Rep 2016; 17:436-447. [PubMed: 27705792]

[70]. Cherrier DE, Serafini N, Di Santo JP: Innate Lymphoid Cell Development: A T Cell Perspective. Immunity 2018; 48:1091-1103. [PubMed: 29924975]

[71]. Zook EC, Kee BL: Development of innate lymphoid cells. Nat Immunol 2016; 17:775-82. [PubMed: 27328007]

[72]. Yun TJ, Bevan MJ: Notch-regulated ankyrin-repeat protein inhibits Notch1 signaling: multiple Notch1 signaling pathways involved in T cell development. J Immunol 2003; 170:5834-5841. [PubMed: 12794108]

[73]. Smith S, Tripathi R, Goodings C, Cleveland S, Mathias E, Hardaway JA, Elliott N, Yi Y, Chen X, Downing J et al.: LIM domain only-2 (LMO2) induces T-cell leukemia by two distinct pathways. PLoS One 2014; 9:e85883. [PubMed: 24465765]

[74]. Tsang JC, Yu Y, Burke S, Buettner F, Wang C, Kolodziejczyk AA, Teichmann SA, Lu L, Liu P: Single-cell transcriptomic reconstruction reveals cell cycle and multi-lineage differentiation defects in Bcl11a-deficient hematopoietic stem cells. Genome Biol 2015; 16:178. [PubMed: 26387834]

[75]. Wu X, Satpathy AT, Wumesh KC, Liu P, Murphy TL, Murphy KM: Bcl11a controls Flt3 expression in early hematopoietic progenitors and is required for $\mathrm{pDC}$ development in vivo. PLoS One 2013; 8:e64800. [PubMed: 23741395]

[76]. Shields BJ, Alserihi R, Nasa C, Bogue C, Alexander WS, McCormack MP: Hhex regulates Kit to promote radioresistance of self-renewing thymocytes in Lmo2-transgenic mice. Leukemia 2015; 29:927-38. [PubMed: 25283843]

[77]. Weng AP, Millholland JM, Yashiro-Ohtani Y, Arcangeli ML, Lau A, Wai C, Del Bianco C, Rodriguez CG, Sai H, Tobias J et al.: c-Myc is an important direct target of Notch1 in T-cell acute lymphoblastic leukemia/lymphoma. Genes Dev 2006; 20:2096-2109. [PubMed: 16847353]

[78]. Weerkamp F, Luis TC, Naber BA, Koster EE, Jeannotte L, van Dongen JJ, Staal FJ: Identification of Notch target genes in uncommitted T-cell progenitors: No direct induction of a T-cell specific gene program. Leukemia 2006; 20:1967-1977. [PubMed: 16990763]

[79]. Schmitt TM, De Pooter RF, Gronski MA, Cho SK, Ohashi PS, Zúñiga-Pflücker JC: Induction of $\mathrm{T}$ cell development and establishment of $\mathrm{T}$ cell competence from embryonic stem cells differentiated in vitro. Nat. Immunol 2004; 5:410-417. [PubMed: 15034575]

[80]. Taghon TN, David ES, Zúñiga-Pflücker JC, Rothenberg EV: Delayed, asynchronous, and reversible T-lineage specification induced by Notch/Delta signaling. Genes Dev 2005; 19:96578. [PubMed: 15833919]

[81]. Tydell CC, David-Fung ES, Moore JE, Rowen L, Taghon T, Rothenberg EV: Molecular dissection of prethymic progenitor entry into the $\mathrm{T}$ lymphocyte developmental pathway. $\mathrm{J}$ Immunol 2007; 179:421-38. [PubMed: 17579063]

[82]. Ohmura S, Mizuno S, Oishi H, Ku CJ, Hermann M, Hosoya T, Takahashi S, Engel JD: Lineageaffiliated transcription factors bind the Gata3 Tce1 enhancer to mediate lineage-specific programs. J Clin Invest 2016; 126:865-78. [PubMed: 26808502]

[83]. Franco CB, Scripture-Adams DD, Proekt I, Taghon T, Weiss AH, Yui MA, Adams SL, Diamond RA, Rothenberg EV: Notch/Delta signaling constrains reengineering of pro-T cells by PU.1. Proc Natl Acad Sci U S A 2006; 103:11993-8. [PubMed: 16880393]

[84]. Sambandam A, Maillard I, Zediak VP, Xu L, Gerstein RM, Aster JC, Pear WS, Bhandoola A: Notch signaling controls the generation and differentiation of early $\mathrm{T}$ lineage progenitors. Nat Immunol 2005; 6:663-70. [PubMed: 15951813]

[85]. Wang D, D'Costa J, Civin CI, Friedman AD: C/EBPa directs monocytic commitment of primary myeloid progenitors. Blood 2006; 108:1223-1229. [PubMed: 16645168] 
[86]. Yeamans C, Wang D, Paz-Priel I, Torbett BE, Tenen DG, Friedman AD: C/EBPa binds and activates the PU.1 distal enhancer to induce monocyte lineage commitment. Blood 2007; 110:3136-3142. [PubMed: 17671233]

[87]. Carotta S, Dakic A, D’Amico A, Pang SH, Greig KT, Nutt SL, Wu L: The transcription factor PU.1 controls dendritic cell development and Flt3 cytokine receptor expression in a dosedependent manner. Immunity 2010; 32:628-641. [PubMed: 20510871]

[88]. Stehling-Sun S, Dade J, Nutt SL, DeKoter RP, Camargo FD: Regulation of lymphoid versus myeloid fate 'choice' by the transcription factor Mef2c. Nat. Immunol 2009; 10:289-296. [PubMed: 19169261]

[89]. Landry JR, Bonadies N, Kinston S, Knezevic K, Wilson NK, Oram SH, Janes M, Piltz S, Hammett M, Carter J et al.: Expression of the leukemia oncogene Lmo2 is controlled by an array of tissue-specific elements dispersed over $100 \mathrm{~kb}$ and bound by Tal1/Lmo2, Ets, and Gata factors. Blood 2009; 113:5783-5792. [PubMed: 19171877]

[90]. Okuno Y, Huang G, Rosenbauer F, Evans EK, Radomska HS, Iwasaki H, Akashi K, MoreauGachelin F, Li Y, Zhang P et al.: Potential autoregulation of transcription factor PU.1 by an upstream regulatory element. Mol. Cell Biol 2005; 25:2832-2845. [PubMed: 15767686]

[91]. Leddin M, Perrod C, Hoogenkamp M, Ghani S, Assi S, Heinz S, Wilson NK, Follows G, Schönheit J, Vockentanz L et al.: Two distinct auto-regulatory loops operate at the PU.1 locus in B cells and myeloid cells. Blood 2011; 117:2827-2838. [PubMed: 21239694]

[92]. Zhao JY, Osipovich O, Koues OI, Majumder K, Oltz EM: Activation of Mouse Tcrb: Uncoupling RUNX1 Function from Its Cooperative Binding with ETS1. J Immunol 2017; 199:1131-1141. [PubMed: 28637900]

[93]. Okada H, Watanabe T, Niki M, Takano H, Chiba N, Yanai N, Tani K, Hibino H, Asano S, Mucenski ML et al.: AML1 (-/-) embryos do not express certain hematopoiesis-related gene transcripts including those of the PU.1 gene. Oncogene 1998; 17:2287-2293. [PubMed: 9811459]

[94]. Maurice D, Hooper J, Lang G, Weston K: c-Myb regulates lineage choice in developing thymocytes via its target gene Gata3. EMBO J 2007; 26:3629-3640. [PubMed: 17641686]

[95]. Gimferrer I, Hu T, Simmons A, Wang C, Souabni A, Busslinger M, Bender TP, HernandezHoyos G, Alberola-Ila J: Regulation of GATA-3 expression during CD4 lineage differentiation. J Immunol 2011; 186:3892-3898. [PubMed: 21357543]

*[96]. Harly C, Kenney D, Ren G, Lai B, Raabe T, Yang Q, Cam MC, Xue HH, Zhao K, Bhandoola A: The transcription factor TCF-1 enforces commitment to the innate lymphoid cell lineage. Nat Immunol 2019.This single-cell analysis of the innate cell precursor compartment in wildtype and TCF-1-deficient mice shows the remarkable similarity between lineage commitment in the innate lymphoid lineage and commitment in the T-cell lineage.

[97]. Yang Q, Monticelli LA, Saenz SA, Chi AW, Sonnenberg GF, Tang J, De Obaldia ME, Bailis W, Bryson JL, Toscano $\mathrm{K}$ et al.: T cell factor 1 is required for group 2 innate lymphoid cell generation. Immunity 2013; 38:694-704. [PubMed: 23601684]

[98]. Mielke LA, Groom JR, Rankin LC, Seillet C, Masson F, Putoczki T, Belz GT: TCF-1 controls ILC2 and $\mathrm{NKp} 46^{+} \mathrm{ROR} \gamma \mathrm{t}^{+}$innate lymphocyte differentiation and protection in intestinal inflammation. J Immunol 2013; 191:4383-91. [PubMed: 24038093]

[99]. Li L, Zhang JA, Dose M, Kueh HY, Mosadeghi R, Gounari F, Rothenberg EV: A far downstream enhancer for murine Bcl11b controls its T-cell specific expression. Blood 2013; 122:902-11. [PubMed: 23741008]

[100]. Yu S, Zhou X, Steinke FC, Liu C, Chen SC, Zagorodna O, Jing X, Yokota Y, Meyerholz DK, Mullighan CG et al.: The TCF-1 and LEF-1 transcription factors have cooperative and opposing roles in T cell development and malignancy. Immunity 2012; 37:813-26. [PubMed: 23103132]

[101]. Yagi R, Zhong C, Northrup DL, Yu F, Bouladoux N, Spencer S, Hu G, Barron L, Sharma S, Nakayama T et al.: The transcription factor GATA3 is critical for the development of all IL-7Raexpressing innate lymphoid cells. Immunity 2014; 40:378-88. [PubMed: 24631153]

[102]. Tindemans I, Serafini N, Di Santo JP, Hendriks RW: GATA-3 function in innate and adaptive immunity. Immunity 2014; 41:191-206. [PubMed: 25148023] 
[103]. Zhu J: GATA3 Regulates the Development and Functions of Innate Lymphoid Cell Subsets at Multiple Stages. Front Immunol 2017; 8:1571. [PubMed: 29184556]

[104]. Harly C, Cam M, Kaye J, Bhandoola A: Development and differentiation of early innate lymphoid progenitors. J Exp Med 2018; 215:249-262. [PubMed: 29183988]

[105]. McMillan RE, Sikes ML: Promoter activity 5' of D $\beta 2$ is coordinated by E47, Runx1, and GATA-3. Mol Immunol 2009; 46:3009-3017. [PubMed: 19592096]

[106]. Li L, Leid M, Rothenberg EV: An early T cell lineage commitment checkpoint dependent on the transcription factor Bcl11b. Science 2010; 329:89-93. [PubMed: 20595614]

[107]. Welinder E, Mansson R, Mercer EM, Bryder D, Sigvardsson M, Murre C: The transcription factors E2A and HEB act in concert to induce the expression of FOXO1 in the common lymphoid progenitor. Proc Natl Acad Sci U S A 2011; 108:17402-7. [PubMed: 21972416]

[108]. Thal MA, Carvalho TL, He T, Kim HG, Gao H, Hagman J, Klug CA: Ebf1-mediated downregulation of Id 2 and Id 3 is essential for specification of the B cell lineage. Proc. Natl. Acad. Sci. U.S.A 2009; 106:552-557. [PubMed: 19122139]

[109]. Schwartz R, Engel I, Fallahi-Sichani M, Petrie HT, Murre C: Gene expression patterns define novel roles for $\mathrm{E} 47$ in cell cycle progression, cytokine-mediated signaling, and T lineage development. Proc Natl Acad Sci U S A 2006; 103:9976-81. [PubMed: 16782810]

[110]. Jones-Mason ME, Zhao X, Kappes D, Lasorella A, Iavarone A, Zhuang Y: E protein transcription factors are required for the development of $\mathrm{CD}^{+}$lineage T cells. Immunity 2012; 36:348-61. [PubMed: 22425249]

[111]. Ikawa T, Kawamoto H, Goldrath AW, Murre C: E proteins and Notch signaling cooperate to promote T cell lineage specification and commitment. J Exp Med 2006; 203:1329-42. [PubMed: 16682500]

[112]. Lian RH, Kumar V: Murine natural killer cell progenitors and their requirements for development. Semin. Immunol 2002; 14:453-460. [PubMed: 12457618]

[113]. Ramirez K, Chandler KJ, Spaulding C, Zandi S, Sigvardsson M, Graves BJ, Kee BL: Gene deregulation and chronic activation in natural killer cells deficient in the transcription factor ETS1. Immunity 2012; 36:921-32. [PubMed: 22608498]

[114]. Ikawa T, Fujimoto S, Kawamoto H, Katsura Y, Yokota Y: Commitment to natural killer cells requires the helix-loop-helix inhibitor Id2. Proc. Natl. Acad. Sci. U.S.A 2001; 98:5164-5169. [PubMed: 11296270]

[115]. Boos MD, Yokota Y, Eberl G, Kee BL: Mature natural killer cell and lymphoid tissue-inducing cell development requires Id2-mediated suppression of E protein activity. J. Exp. Med 2007; 204:1119-1130. [PubMed: 17452521]

[116]. Schotte R, Dontje W, Nagasawa M, Yasuda Y, Bakker AQ, Spits H, Blom B: Synergy between IL-15 and Id2 promotes the expansion of human NK progenitor cells, which can be counteracted by the E protein HEB required to drive T cell development. J.Immunol 2010; 184:6670-6679. [PubMed: 20483740]

[117]. Male V, Nisoli I, Kostrzewski T, Allan DSJ, Carlyle JR, Lord GM, Wack A, Brady HJM: The transcription factor E4bp4/Nfil3 controls commitment to the NK lineage and directly regulates Eomes and Id2 expression. J Exp Med 2014; 211:635-42. [PubMed: 24663216]

[118]. Seillet C, Huntington ND, Gangatirkar P, Axelsson E, Minnich M, Brady HJ, Busslinger M, Smyth MJ, Belz GT, Carotta S: Differential requirement for Nfil3 during NK cell development. J Immunol 2014; 192:2667-76. [PubMed: 24532575]

[119]. Seillet C, Rankin LC, Groom JR, Mielke LA, Tellier J, Chopin M, Huntington ND, Belz GT, Carotta S: Nfil3 is required for the development of all innate lymphoid cell subsets. J Exp Med 2014; 211:1733-40. [PubMed: 25092873]

[120]. Geiger TL, Abt MC, Gasteiger G, Firth MA, O’Connor MH, Geary CD, O’Sullivan TE, van den Brink MR, Pamer EG, Hanash AM et al.: Nfil3 is crucial for development of innate lymphoid cells and host protection against intestinal pathogens. J Exp Med 2014; 211:1723-31. [PubMed: 25113970]

[121]. Yu X, Wang Y, Deng M, Li Y, Ruhn KA, Zhang CC, Hooper LV: The basic leucine zipper transcription factor NFIL3 directs the development of a common innate lymphoid cell precursor. Elife 2014; 3 . 
[122]. Xu W, Domingues RG, Fonseca-Pereira D, Ferreira M, Ribeiro H, Lopez-Lastra S, Motomura Y, Moreira-Santos L, Bihl F, Braud V et al.: NFIL3 orchestrates the emergence of common helper innate lymphoid cell precursors. Cell Rep 2015; 10:2043-54. [PubMed: 25801035]

[123]. Levanon D, Negreanu V, Lotem J, Bone KR, Brenner O, Leshkowitz D, Groner Y: Transcription factor Runx3 regulates interleukin-15-dependent natural killer cell activation. Mol Cell Biol 2014; 34:1158-69. [PubMed: 24421391]

[124]. Ebihara T, Song C, Ryu SH, Plougastel-Douglas B, Yang L, Levanon D, Groner Y, Bern MD, Stappenbeck TS, Colonna M et al.: Runx3 specifies lineage commitment of innate lymphoid cells. Nat Immunol 2015; 16:1124-33. [PubMed: 26414766]

[125]. Constantinides MG, McDonald BD, Verhoef PA, Bendelac A: A committed precursor to innate lymphoid cells. Nature 2014; 508:397-401. [PubMed: 24509713] 
Box 1:

\section{Latent gene network circuits.}

\section{Latent circuit 1: myeloid cell potential.}

Latent circuit 1 is triggered when high levels of PU.1 cause an inhibition of Notch signaling (mechanism still to be determined). The combination of high PU.1 and low Notch signaling reveals novel responses. T-cell program genes $T c f 7, B c 111 b$, and Ets 1 (group C), Tcf3 and Tcf12 (encoding E2A and HEB, group D), and Gfi1, Runx1, and $M y b$ (group E) are all substantially repressed. At the same time, innate immunityassociated Cebp family and Irf family regulatory genes are sharply up-regulated. Most of the repressive effects may be indirect, as shown with a dominant repressor form of PU.1 [37]; a proximate inhibitor of the T-cell program could be C/EBPa [11]. Note that normal levels of Notch signaling in the thymus completely block these responses to PU.1 via Circuit 2, even up to at least $3 \times$ physiological Spil expression levels.

\section{Latent circuit 2: mast-cell potential.}

Although latent circuit 2 is not documented at genome-wide scope, elevated GATA-3 blocks T-cell development [47] and can redirect cells toward a mast cell program [33]. Elevated GATA-3 blocks expression of group B regulatory factors PU.1 and Bcl11a, which is also needed for early T-cell viability [66], and severely downregulates the crucial growth factor receptor IL-7R, while it upregulates Kit and mast-cell genes [33]. If Notch signaling is sustained, the cells die in these conditions. Withdrawal of Notch signaling causes them to lose $T c f 7$ expression as well, but they can then activate a full mast-cell program if supported by Kit ligand.

\section{Latent circuit 3: innate lymphoid/ innate-like $\mathbf{T}$ cell program.}

Bcl11b activation is linked to commitment, but the response to deletion of $B c 111 b$ in late DN2b/DN3 cells does not restore the stem/progenitor cell state. Instead, it causes upregulation both of genes expressed in non-T programs and of genes expressed in the effector stages of later T and ILC or natural killer cell development, including Id2, Nfil3, Zbtb16, and others [17,18,67]. Tcf7, Gata3, and Ets1 expression is preserved intact [17]. In general, ILC and effector T cell programs share use of the E protein antagonist, Id2 $[3,15,42,68-71]$. In pro-T cells, specific parts of the Bcl11b regulome in fact reflect its ability to help sustain maximal E protein activity by keeping $I d 2$ repressed: for example, both the increase in Zbtb16 expression and the decrease in T-cell receptor signaling component coding genes $C d 3 g, C d 3 d$, and $C d 3 e$ when $B c 111 b$ is deleted are much attenuated if both $I d 2$ and $B c 111 \mathrm{~b}$ are deleted together [17]. 


\section{Highlights:}

- A gene regulatory network model for T-cell specification is based on functional data

- $\quad$ Five modules of regulatory genes are linked by defined, stage-dependent subcircuits

- $\quad$ Pro-T cells also prime three latent network circuits that are normally suppressed

- Actual system kinetics are also constrained by slow epigenetic state changes

- Regulator genomic binding site choices are competitive, affected by other factors 
A
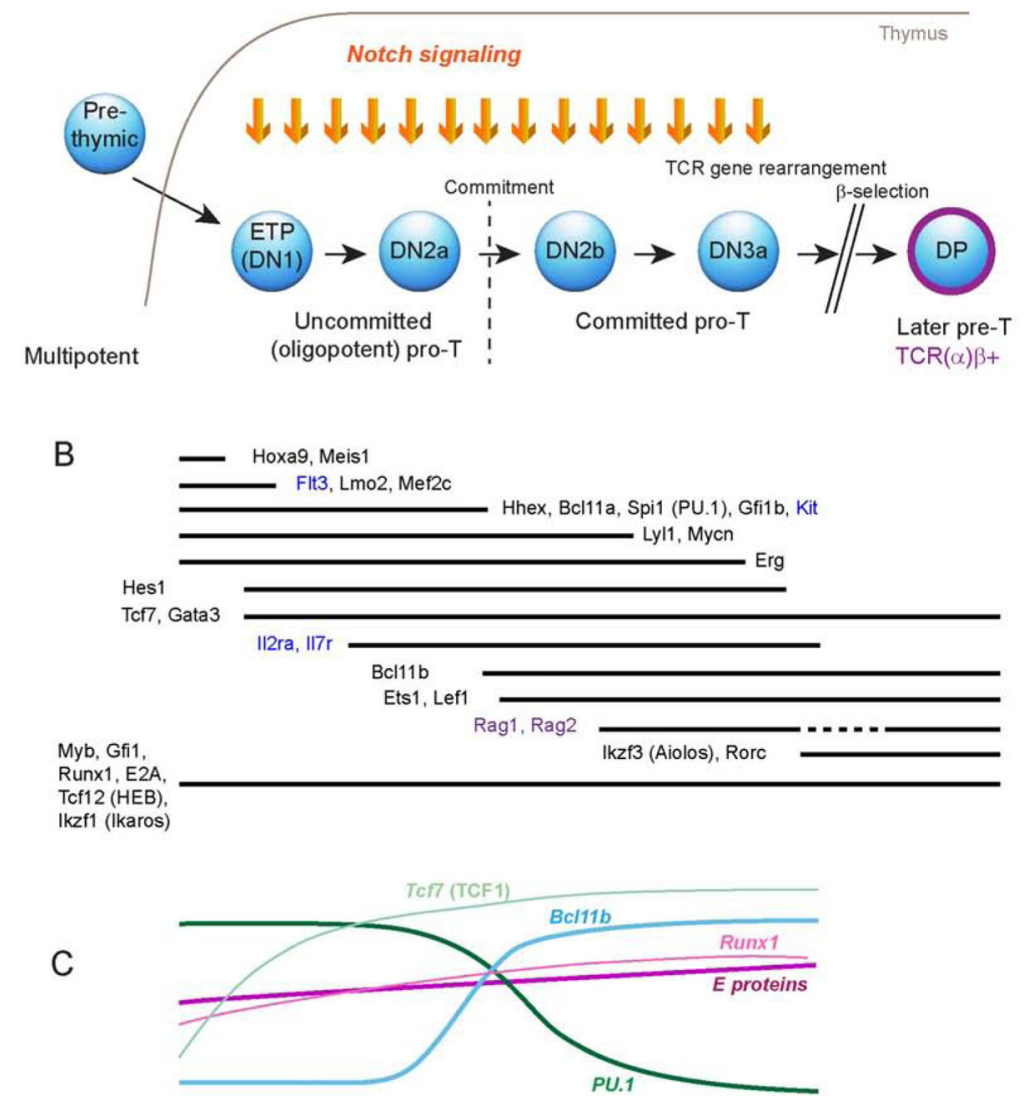

D
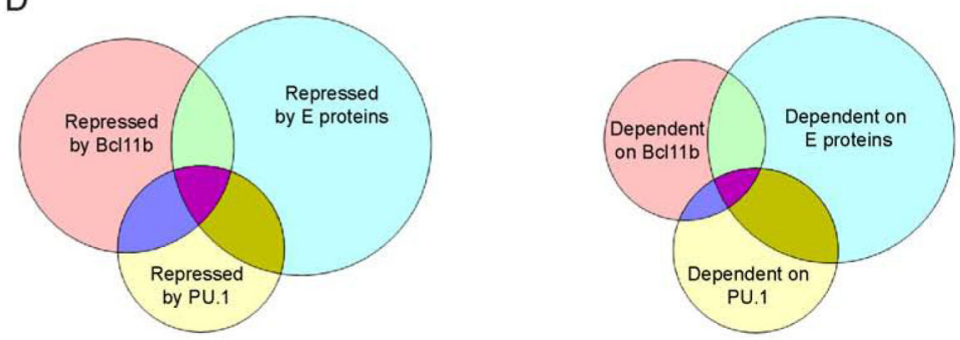

Fig. 1. Outline of T-cell development and T-cell gene regulatory network

A. Diagram of mouse T-cell developmental stages in the mouse. Cells in early T-cell developmental stages are called "DN" for CD4, CD8 "double negative" (in later stages, the cells express either or both of these markers). The most primitive cells in any cohort of DN cells are Early T-cell Precursors (ETPs: $\left.\mathrm{Kit}^{+} \mathrm{CD} 44^{+} \mathrm{CD} 25^{-}\right)$, then DN2a $\left(\mathrm{Kit}^{++} \mathrm{CD} 44^{+}\right.$ $\left.\mathrm{CD} 25^{+}\right)$, DN2b $\left(\mathrm{Kit}^{\text {int }} \mathrm{CD} 44^{+} \mathrm{CD} 25^{+}\right.$), and DN3a (Kit $\left.{ }^{\text {low }} \mathrm{CD} 44^{\text {low }} \mathrm{CD} 25^{+} \mathrm{CD} 28^{-}\right)$. If and only if TCR gene recombination happens successfully in DN3a cells so that a TCR protein can be expressed, the cells can differentiate further in the T cell pathway. Cells successfully expressing a TCR $\beta$ chain through a process dependent on Rag1, Rag2, Dntt, and auxiliary signaling molecules (CD3 $\gamma, \delta, \varepsilon$ and others) proceed to $\mathrm{CD} 4^{+} \mathrm{CD} 8^{+}(\mathrm{DP})$ stage, when both 
chains of the $\alpha \beta$ TCR are first expressed, and then to other stages beyond the scope of this review.

B. Simplified summary of expression patterns of regulatory genes and cytokine receptors through early T-cell developmental stages until full TCR expression. Approximate "on" and "off" states are depicted; more quantitative modulation occurs for some factors.

C. Schematic contrasting the expression patterns of PU.1, Bcl11b, and E proteins relative to T-cell lineage commitment. Vertical axis approximates log scale values ( 100 fold range). "E proteins": combination of E2A (stably expressed) with HEB (moderately increasing during T-cell specification). Expression patterns of TCF1 (Tcf7) and Runx1 are also shown. C. Venn diagrams showing the independent but intersecting effects of PU.1, Bcl11b, and E proteins (E2A and/or HEB) relative to each other as determined by genome-wide transcriptome analysis in acute stage-specific gene knockout experiments. Left panel, dark purple intersection: genes repressed by all three factors are enriched for innate lymphoid program genes. Data for PU.1, from [16] Table S5, represent effects of acute PU.1 deletion in adult bone marrow-derived DN2a-DN2b cells. Data for Bcl11b, from [17] Table S3, represent genes that are significantly differentially expressed in at least two of three $B c 111 b$ gene knockout protocols used in adult intrathymic or adult bone marrow-derived DN2b-DN3 cells. Data for E proteins represent the effects of a double knockout of E2A and HEB (Tcf3 and Tcf12) using II7r-Cre in fetal ETP cells from [15](GSE95337). Note that fetal ETPs precociously express many genes that are only expressed in more advanced adult pro-T cells, as well as genes expressed in adult ETPs $[15,34,65]$. 

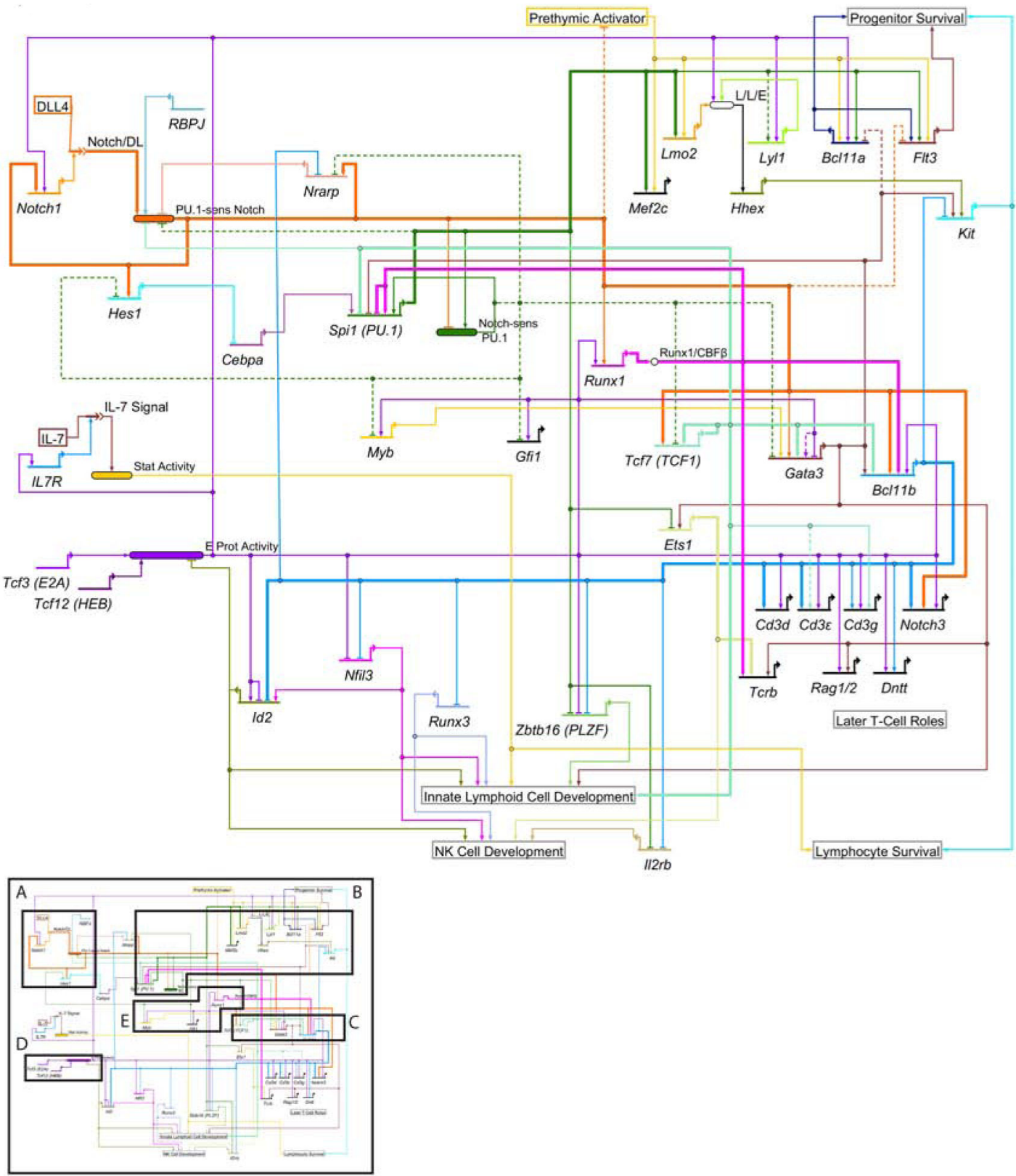

Fig. 2. Gene network model for early T-cell specification

Shown is an updated, streamlined version of the network developed in ref. [18], focusing on important nodes and consistently supported linkages (sources cited in Table 1). Inset at bottom shows boundaries of groups described in the text. Group A regulators centered on Notch are in upper left. Group B regulators are in upper right and include PU.1 (encoded by Spi1). Group C regulators $T c f 7$, Gata3, Bcl11b, and Ets1 are in middle right. Group D regulators, centered around E proteins E2A (encoded by Tcf3) and HEB (encoded by Tcf12), are in lower left. Group E regulators, represented by Myb, Gfi1, and Runx 1, are in center (Ikaros family regulators, not shown). Lower right: genes associated with assembly of a signaling-competent TCR complex, essential for later T cell development. Lower center: genes associated with alternative innate lymphoid fates. Id2 (adjacent to group D) is an 
antagonist of Group D which is also critical for innate lymphoid cell and natural killer cell maturation and expansion (lower center).

Intrinsic PU.1 and ligand-dependent Notch signaling can modulate each other (upper left and center), but the relationship is asymmetric. Notch signaling narrows the range of PU.1 action but does not reduce its intensity, whereas high-level PU.1 can globally inhibit Notch signaling effects. The effect of PU.1 gain of function on target genes has been dissected out from the Notch inhibitory effect in [12], and built into the experimental design in [16]. However, in normal pro-T cells, Notch signaling is predominant over natural levels of PU.1 activity. 
TABLE 1:

Table of sources for Gene Regulatory Network Model

\begin{tabular}{|c|c|c|c|c|}
\hline SOURCE & TARGET & Direction & Notes & References \\
\hline Notch1 & Intercellular Notch/DL & activate & definition & \\
\hline DLL4 & Intercellular Notch/DL & activate & definition & \\
\hline NotchDL & PU.1-sens-Notch & activate & definition & \\
\hline RBPJ & PU.1-sens-Notch & activate & definition & \\
\hline Nrarp & PU.1-sens-Notch & repress & & [72] \\
\hline Prethymic Activator & Bcl11a & activate & assumed by expression & \\
\hline Prethymic Activator & Mef2c & activate & assumed by expression & \\
\hline Prethymic Activator & Lmo2 & activate & assumed by expression & \\
\hline Prethymic Activator & Flt3 & activate & assumed by expression & \\
\hline Mef2c & (none noted) & & & \\
\hline Lmo2 & L/L/E Activity & activate & definition & \\
\hline L/L/E activity & Hhex & activate & & [73] \\
\hline Lyl1 & L/L/E Activity & activate & definition & \\
\hline Bcl11a & Progenitor survival & activate & & {$[66,74]$} \\
\hline Bcl11a & Flt3 & activate & & [75] \\
\hline Hhex & Kit & activate & & [76] \\
\hline Kit & Progenitor survival & activate & & \\
\hline Kit & Lymphocyte survival & activate & & \\
\hline Flt3 & Progenitor survival & activate & & \\
\hline Hes1 & Cebpa & repress & & [40] \\
\hline PU.1-sens Notch & Notch1 & activate & & {$[12,77,78]$} \\
\hline PU.1-sens Notch & Notch3 & activate & & {$[12,77]$} \\
\hline PU.1-sens Notch & Tcf7 & activate & & {$[26,27]$} \\
\hline PU.1-sens Notch & Hes 1 & activate & & {$[12,77,78]$} \\
\hline PU.1-sens Notch & Gata3 & activate & functionally direct? & [79-82] \\
\hline PU.1-sens Notch & Runx1 & activate & & {$[12]$} \\
\hline PU.1-sens Notch & Nrarp & activate & & {$[12,78]$} \\
\hline PU.1-sens Notch & $\mathrm{Bc} 111 \mathrm{~b}$ & activate & & {$[6,59]$} \\
\hline PU.1-sens Notch & Prethymic activator & repress & conjectural & \\
\hline PU.1-sens Notch & Notch-sens PU.1 & repress & definition & {$[12,16,83]$} \\
\hline PU.1-sens Notch & Flt3 & repress & & [84] \\
\hline Cebpa & Spil & activate & & {$[11,85,86]$} \\
\hline Spi1 & Flt3 & activate & in prethymic cells & [87] \\
\hline Spi1 & Bcl11a & activate & & {$[12,16]$} \\
\hline Spi1 & Lyl1 & activate & only w/ Notch signal & {$[12]$} \\
\hline Spi1 & Mef2c & activate & & {$[16,37,88]$} \\
\hline Spi1 & Notch-sens PU.1 & activate & definition & \\
\hline Spi1 & Lmo2 & activate & & {$[12,16,37,89]$} \\
\hline Spi1 & Zbtb16 & repress & & {$[16,37]$} \\
\hline
\end{tabular}




\begin{tabular}{|c|c|c|c|c|}
\hline SOURCE & TARGET & Direction & Notes & References \\
\hline Spi1 & $\mathrm{I} 12 \mathrm{rb}$ & repress & & {$[16,37]$} \\
\hline Spi1 & Ets1 & repress & & {$[12,16,37]$} \\
\hline Spi1 & PU.1-sens Notch & repress & & {$[11,12,83]$} \\
\hline Notch-sens PU.1 & Spi1(PU.1) & activate & autoregulation limited in early $\mathrm{T}$ & {$[90,91]$} \\
\hline Notch-sens PU.1 & Gfi1 & repress & may not be direct & [12] \\
\hline Notch-sens PU.1 & Hes1 & repress & direct and indirect & {$[12,83]$} \\
\hline Notch-sens PU.1 & Gata3 & repress & may not be direct & {$[12]$} \\
\hline Notch-sens PU.1 & Nrarp & repress & may not be direct & [12] \\
\hline Notch-sens PU.1 & Tcf7 & repress & may not be direct & {$[12,37,83]$} \\
\hline Notch-sens PU.1 & Myb & repress & may not be direct & {$[12,37,83]$} \\
\hline Runx1 & Runx $1 / \mathrm{CBFb}$ & activate & definition & \\
\hline Runx/CBFb & Tcrb & activate & & [92] \\
\hline Runx/CBFb & Spil & activate & bivalent & {$[35,93]$} \\
\hline Runx/CBFb & Bcl11b & activate & & [6] \\
\hline Runx/CBFb & Spi1 & repress & bivalent & {$[35,36]$} \\
\hline IL7r & IL7signal & activate & definition & \\
\hline Il7 & IL7signal & activate & definition & \\
\hline IL7signal & Stat activity & activate & definition & \\
\hline Stat activity & Lymphocyte survival & activate & & \\
\hline Stat activity & Innate lymphoid cell devel & activate & & \\
\hline Myb & Gata3 & activate & & {$[12,94,95]$} \\
\hline Gfi1 & (none noted) & & & \\
\hline Tef7 & Tcf7 & activate & & [27] \\
\hline Tef7 & $\mathrm{Cd} 3 \mathrm{~g}$ & activate & & [27] \\
\hline Tcf7 & $\mathrm{Cd} 3 \mathrm{e}$ & activate & & [26] \\
\hline Tef7 & Innate Lymphoid cell devel & activate & & [96-98] \\
\hline Tef7 & Gata3 & activate & & [27] \\
\hline Tcf7 & $\mathrm{Bc} 111 \mathrm{~b}$ & activate & & {$[6,27,99]$} \\
\hline Tcf7 & Spi1 & repress & & [32]; support in [6] \\
\hline Tef7 & PU.1-sens Notch & repress & & {$[22,100]$} \\
\hline Gata3 & Innate lymphoid cell devel & activate & & [101-104] \\
\hline Gata3 & Tcrb & activate & & [105] \\
\hline Gata3 & Kit & activate & & {$[33,34]$} \\
\hline Gata3 & Bcl11b & activate & & {$[6,34,48]$} \\
\hline Gata3 & $\operatorname{Rag} 1 / 2$ & activate & & [48] \\
\hline Gata3 & Ets1 & activate & & {$[34,48]$} \\
\hline Gata3 & Spi1 & repress & & {$[33,34]$} \\
\hline Gata3 & Bcl11a & repress & & {$[34,48]$} \\
\hline Bcl11b & $\mathrm{Cd} 3 \mathrm{e}$ & activate & & {$[17,18]$} \\
\hline Bcl11b & $\mathrm{Cd} 3 \mathrm{~d}$ & activate & & {$[17,18]$} \\
\hline Bcl11b & $\mathrm{Cd} 3 \mathrm{~g}$ & activate & & {$[17,18]$} \\
\hline Bcl11b & Dntt & activate & & {$[17,18]$} \\
\hline
\end{tabular}




\begin{tabular}{|c|c|c|c|c|}
\hline SOURCE & TARGET & Direction & Notes & References \\
\hline Bcl11b & Notch3 & activate & & {$[17,18]$} \\
\hline Bcl11b & Runx3 & repress & & {$[17,18]$} \\
\hline Bcl11b & $\operatorname{Id} 2$ & repress & & {$[17,18,67,106]$} \\
\hline Bcl11b & Kit & repress & & {$[17,18]$} \\
\hline Bcl11b & Zbtb16 & repress & & {$[17,18,106]$} \\
\hline Bcl11b & Nfil3 & repress & & {$[17,18,67]$} \\
\hline Bcl11b & Nrarp & repress & & {$[17,18]$} \\
\hline Bcl11b & $\mathrm{I} 12 \mathrm{rb}$ & repress & & {$[17,18,67]$} \\
\hline Tcf3 & E prot activity & activate & definition & \\
\hline Tef12 & E prot activity & activate & definition & \\
\hline E prot activity & $\mathrm{Cd} 3 \mathrm{~g}$ & activate & & [47] \\
\hline E prot activity & Lyl1 & activate & & {$[15,47]$} \\
\hline E prot activity & Notch3 & activate & & [47] \\
\hline E prot activity & $\mathrm{I} 17 \mathrm{r}$ & activate & & [107] \\
\hline E prot activity & $\mathrm{Id} 2$ & activate & potential in Il7r- pro-B cells & {$[107,108]$} \\
\hline E prot activity & $\mathrm{Cd} 3 \mathrm{~d}$ & activate & & {$[15]$} \\
\hline E prot activity & Gfil & activate & & {$[47,109]$} \\
\hline E prot activity & Notch1 & activate & & {$[12,15,41]$} \\
\hline E prot activity & Gata3 & activate & bivalent & [110] \\
\hline E prot activity & Bcl11a & activate & & {$[15,17,61,111]$} \\
\hline E prot activity & $\mathrm{Cd} 3 \mathrm{e}$ & activate & & {$[15,28,47]$} \\
\hline E prot activity & Dntt & activate & & {$[47,107]$} \\
\hline E prot activity & $\operatorname{Rag} 1 / 2$ & activate & & {$[109,111]$} \\
\hline E prot activity & Myb & activate & & {$[15,28]$} \\
\hline E prot activity & Runx 1 & activate & & {$[12,15,47]$} \\
\hline E prot activity & $\mathrm{Bc} 111 \mathrm{~b}$ & activate & & {$[28,47]$} \\
\hline E prot activity & L/L/E activity & activate & definition & \\
\hline E prot activity & Zbtb16 & repress & & {$[15,47]$} \\
\hline E prot activity & Nfil3 & repress & & {$[15,47]$} \\
\hline E prot activity & Id 2 & repress & bivalent & {$[15,47]$} \\
\hline E prot activity & Gata3 & repress & bivalent & {$[15,47]$} \\
\hline Ets1 & Tcrb & activate & & [92] \\
\hline Ets1 & NK cell development & activate & & {$[112,113]$} \\
\hline Id2 & NK cell development & activate & & {$[42,112,114-116]$} \\
\hline Id2 & Innate lymphoid cell devel & activate & & {$[15,69,71]$} \\
\hline Id2 & E prot activity & repress & definition & \\
\hline Nfil3 & $\operatorname{Id} 2$ & activate & & [117] \\
\hline Nfil3 & NK cell development & activate & & {$[117,118]$} \\
\hline Nfil3 & Innate lymphoid cell devel & activate & & [119-122] \\
\hline Runx3 & NK cell development & activate & limited roles & {$[123]$} \\
\hline Runx3 & Innate lymphoid cell devel & activate & limited roles & [124] \\
\hline Zbtb16 & Innate lymphoid cell devel & activate & & {$[125]$} \\
\hline
\end{tabular}




\begin{tabular}{|c|c|c|c|c|}
\hline SOURCE & TARGET & Direction & Notes & References \\
\hline Il2rb & NK cell development & activate & & [112] \\
\hline Notch3 & (none noted) & & & \\
\hline Cd3d & (none noted) & & to TCR & \\
\hline Cd3e & (none noted) & & to TCR & \\
\hline Cd3g & (none noted) & & to TCR & \\
\hline Tcrb & (none noted) & & to TCR & \\
\hline Rag1/2 & (none noted) & & to TCR & \\
\hline Dntt & (none noted) & & to $\mathrm{TCR}$ & \\
\hline
\end{tabular}

Sources are given for relationships shown in Fig. 2. Repression targets are shown in red. "Definition": well-established property of a molecule's function, such as the ligand-receptor interactions for IL-7 receptor or Notch. Transcriptional activation of any part of the Tcrb locus is indicated as "Tcrb", with the understanding that this extremely large and complex locus has many additional sites of regulation as well. "Limited roles": demonstrated roles are in particular subsets, not necessarily all subsets of this cell type. 